\title{
Factors Influencing Technology Transfer for Sustainable Construction Management in Nigeria
}

\author{
Iroegbu Udochukwu Frank*, Rong Du \\ Xidian University, Xi'an, China \\ Email: ^frankyudj@yahoo.com
}

How to cite this paper: Frank, I.U. and Du, R. (2018) Factors Influencing Technology Transfer for Sustainable Construction Management in Nigeria. Engineering, 10, 769-783.

https://doi.org/10.4236/eng.2018.1011054

Received: October 11, 2018

Accepted: November 12, 2018

Published: November 15, 2018

Copyright $\odot 2018$ by authors and Scientific Research Publishing Inc. This work is licensed under the Creative Commons Attribution International License (CC BY 4.0).

http://creativecommons.org/licenses/by/4.0/

Open Access

\begin{abstract}
The move to embrace sustainable building is an international paradigm with the desire for sustainable development in society. Developing countries, however, are the most susceptible regions to unsustainable development. This study focused on factors influencing Technology Transfer in Construction Management in Nigeria. Questionnaires were applied to collect primary data. A total of 55 registered architectures, quantity surveyors and engineers were interviewed. The data were analyzed and both descriptive and inferential statistics were applied in the study. The findings show that research on sustainability and involvement of stakeholders influence the success of technology transfer. These findings have managerial implications on technology transfer to attain sustained development in the construction industry for many developing countries.
\end{abstract}

\section{Keywords}

Nigeria, Technology Transfer, Construction, Management, Sustainable Development

\section{Introduction}

Internationally, the construction sector has been primarily linked to the depletion of resources and use of energy, changes in the ecosystem and global warming. For instance, in North America, structures use about two-fifths of the total power generated, nearly three-quarters of the overall electricity and made approximately two-fifths of primary Carbon dioxide gas discharges.

Furthermore, buildings are responsible for consuming over one in ten of the freshwater across the globe, a quarter of trees cut, and two-fifths of material and 
energy use worldwide [1]. The outcomes validate the value and timeliness of critical issues involving the architectural, engineering and construction (AEC) industry to promote green building. The concept is essential in the conservation of earth's resources and fostering improved living standards internationally. In the international setting, sustainable construction is described as the entire process that sometimes from the excavation of raw materials, planning, blueprint, and the establishment of structures, and finally ends with the pulling down and recycling of the secondary waste materials. Green building requires a distinct perception of cost, quality, and time control something that has been overlooked in the traditional construction sector [2]. It embraces a new criterion which prioritizes less resource utilization and environmental protocols to promote a pleasant surrounding.

The radical change in the sector has a socio-cultural and environmental impact in the international setting [3]. It has provided the necessity to formulate policies for green construction. The terminology "green building guidelines" refer to "the rules that examine the environmental outcomes from the 'whole building' perspective over the building's service life" [4]. Many states, for instance, America, Britain, China, and South Africa have also enacted the protocols or are on the verge of formulating the policies. The US Green Building Council (USGBC) was among the pioneers that began Leadership in Energy and Environmental Design (LEED) guidelines in 2000. Currently, LEED has over 12,659 qualified or listed ventures in all the fifty states in America and over eighty-five designated ventures in sixty-nine nations [5]. Some third world nations, more so the fast developing states, for instance, India, have also begun taking steps in this region. According to this particular investigation, the phrase developing countries implies the partly industrialized nations that mostly have low GDP or domestic private capital to fund the projects to promote economic development according to IMF [6]. The quick move to put operation these requirements has the potential to assist in reducing over-exploitation of non-renewable and natural resource deposits in these nations although there are many bottlenecks [7].

A transfer is the movement of an item from one location to another. This means there have to be two active parties for a successful transfer process, the transferor and the recipient (transferee). This research is bent on seeking answers on the factors that influence transfer from the transferee's point of view, that is, from Nigeria's end as the recipient of technologies from developed countries

\section{Research Question}

The study aims at examining the factors influencing technology transfer in $\mathrm{Ni}$ geria. To achieve this aim, by the following guided objectives:

1) To assess the status of sustainable building to Nigeria's construction industry. 
2) To explore the influence of research on sustainable building construction on the success of technology transfer.

3) To explore the influence of the involvement of stakeholders in building construction on the success of technology transfer.

\section{Literature Review}

The Brundtland Commission suggested the idea of sustainable development in 1972 with the intention of "Meeting the necessities and demands of the current without affecting the capacity of the coming generations to satisfy their needs." Interestingly, this description has changed since then. At the United Nations Earth Summit organized by the UNDP [8] in Brazil's city of Rio de Janeiro, green construction was described as "Enhancing the lifestyle of people at the same time operating within the carrying capacity of supporting ecosystems." The meaning affected the socio-economic-environmental development and was subsequently embraced globally.

Although there are many definitions of the concept, the aims of green construction are universal. This is a strategy for developing the sector to shift towards attaining sustainable development, considering the macroeconomic environmental factors. Ref [3] sustainable construction has been described extensively as "the entire procedure that begins with the sourcing of raw materials, planning, design, and development of structures, and ends with pulling down and management of the secondary waste materials." Ref [1], the traditional construction design concentrates on the cost, performance and quality objectives. On the other hand, green construction also considers controlling the depletion of resources, mitigating environmental degradation, and promoting a healthy environment.

Globally, mostly in developed countries and the fast developing countries, environmental certification systems have been designed as a means for benchmarking buildings towards sustainable development. They provide a practical model for examining structure environmental performance and combining green construction into developing and the construction methods; as it can be applied as a design instrument through coming up with sustainable design priorities and goals, formulating practical design plans; and choosing performance parameters to provide a roadmap for project design and decisionmaking procedures. They can also be applied as administration tools to organize and address environmental issues in the design, construction, and operations stages.

\subsection{Sustainable Construction Technology}

Technology is the "combination of knowledge and skills embodied in products, with product technological features and production processes that are comprised of a complicated inextricably interlinked process technology elements: techno-ware which entails equipment, tools, and machines, human-ware, info-ware 
and organ-ware "(organizational framework)" as alluded by [9]. Ofori [10] noted that technology in the construction sector relates to materials, plant and equipment, organizations, policies and information systems incorporated in planning, designing, constructing, maintaining, modification and demolition of buildings and infrastructure.

Appropriate technologies is defined as "the application of technological styles that do not destroy the ecosystem and local social and cultural variables" [11]. For ecologically sustainable building, it is accepted that technology is appropriate when it does not cause effects that undermine the ecological health of a particular region. It must also fit the economic and social environments.

It has been agreed that the critical decisions relating to the construction technology, materials utilized and the relevant skills are specified at the initial stages of project design as opposed to midway during the construction process [12]. Therefore, it is the responsibility of the designer to evaluate the guidelines for making use of the appropriate technology. Ofori [13] provides a useful framework for analyzing the techniques and materials employed in the construction sector of developing countries regarding sustainable development requirements (Table 1).

\subsection{Research and Development on Sustainable Building Construction}

Promoting research and development (R\&D) through investment is critical in helping a nation develop new technologies, products, and services which are important factors that help corporations maintain their competitive edge in the international markets. For many years, the $R \& D$ department in the construction sector has been neglected compared to the same office in the manufacturing industry. However, corporations are on the verge of incorporating R\&D in construction activities. The Race for Global Advantage in the construction industry has put measures to support the green initiative that includes increasing state $\mathrm{R} \& \mathrm{D}$ funding, training manpower, and promoting $\mathrm{R} \& \mathrm{D}$ tax incentives to encourage global R\&D investment Ref [12].

\subsection{Involvement of Stakeholders in Building Construction}

Every construction project has a number of stakeholders who must take part in project execution. The primary participants include project designers, customers, contractors and project managers are some of the project stakeholders who directly influence the implementation process. Project implementation strategies are often determined by several factors such as power exerted, interests, roles of stakeholders and risks among many other forces. Some of the key stakeholders in a construction project include clients, project designers, contractors, and managers. Olander [14] defines "stakeholders as any group or person capable of influencing, or is affected by, the attainment of a firm's goals". This definition is extensive and can be enhanced by integrating the element of participation in decision making and sessions in addition to enjoying or suffering losses from the 
Table 1. Below shows some attributes of sustainable characteristics.

\begin{tabular}{|c|c|}
\hline Aspects & Comments \\
\hline $\begin{array}{l}\text { Low } \\
\text { environmental } \\
\text { impact }\end{array}$ & $\begin{array}{l}\text { Less harmful discharges to the environment in processes, application or } \\
\text { disposal non-toxic releases that benefit the environment indirectly through its } \\
\text { efficiency }\end{array}$ \\
\hline $\begin{array}{l}\text { Resource } \\
\text { efficiency }\end{array}$ & $\begin{array}{l}\text { Prudent use of resources, mostly through recycling material based on } \\
\text { renewable resources and energy. Efficient use of energy in production and use } \\
\text { durable, reusable or recyclable }\end{array}$ \\
\hline $\begin{array}{l}\text { Economic } \\
\text { advantages }\end{array}$ & $\begin{array}{l}\text { Economically cost-effective compared to the typical product or service } \\
\text { incorporate externalities in the market price can be financed by the user } \\
\text { through various financial saving streams improve productivity or } \\
\text { competitiveness of industry and commerce. }\end{array}$ \\
\hline Social advantages & $\begin{array}{l}\text { Enhance or maintain lifestyle readily available and accessible to all classes and } \\
\text { cultures consistent with themes of decentralization, individual control, } \\
\text { democracy }\end{array}$ \\
\hline
\end{tabular}

Source: Ofori (2000).

results of decisions. They take part in wealth-creating initiatives and therefore stand to enjoy benefits or suffer losses of a project. Hence, a stakeholder is described as a person or team that has a personal interest in the implementation of a project. The stakeholder scope can comprise some elements of rights or ownership. There is both a direct and indirect reciprocal association between a stakeholder and an organization or project; the party has the capacity to influence or be affected by the activities of the other. Project customers are the internal stakeholder and mostly have administrative responsibilities and authority. On the other hand, the owner can be a syndicate that has the power to entrust administrative duties to another party. In many cases, they invest their financial resources in a project and organizations or individuals who have a contract with the project owner. The local communities, state, prospect consumers, supervisors, environmentalists, and the press are examples of external stakeholders.

\section{Theoretical Backgrounds}

This section focuses on the numerous factors that are mostly taken into consideration during a construction venture. Most of these factors are unknown, uncertain, unwanted and mostly unforeseen. This is the nature of risk. Threats cannot be eradicated but can be controlled to a certain degree.

\subsection{Conceptual Framework}

The conceptual framework depicts the outcome and predictor variables. The outcome variable in this investigation is the success of technology transfer. The predictor variables included the Research and development on sustainability and involvement of stakeholders (Figure 1).

\subsection{Research Hypothesis}

The construction industry, as most of the other sectors in the developing countries, is faced with low technological capabilities. Technology Development and 


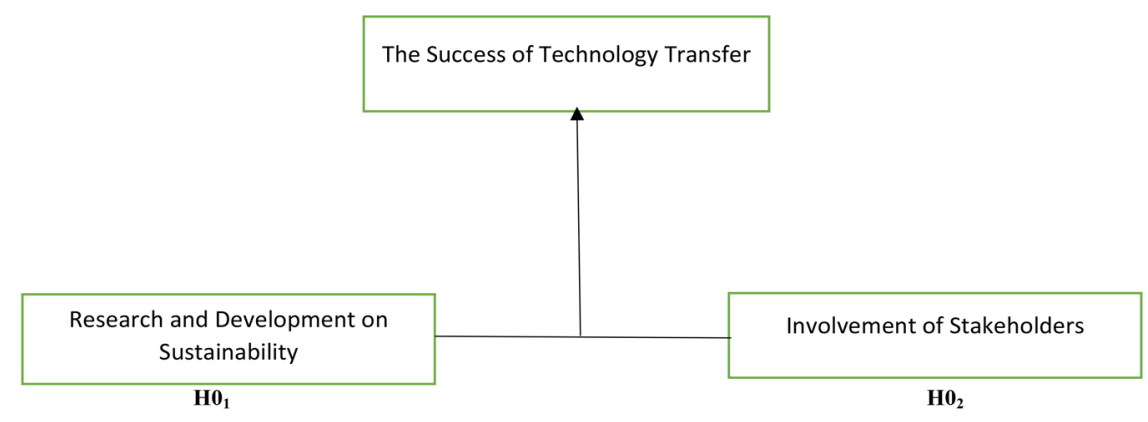

Researcher 2018

Figure 1. Conceptual framework for studying the association between the research on sustainability and involvement of stakeholders in the success of technology transfer.

Technology Transfer, leads to ways of uplifting the technological awareness and implementation in developing countries. This helps in improving sustainability in building through technology transfer and diffusion. Technology transfer expands a construction industry's technical capability which is very important and in the interest of many developing countries. Watermeyer [15] recommends developing countries to develop appropriate technologies to succeed in their endeavors to change the status quo of their construction industries.

The hypotheses examined how each of the predictor variables contributed to the outcome variable as presented below;

$\mathrm{HO}_{1}$ : Research on the sustainability of technology transfer influence technology transfer.

Organizations ought to Develop the institutional capacity of the university research in order to provide technology transfer services and enable specific technology transfer activities such as training of the educated and specialized human resources, the development of new products and technology services, supporting and promoting new patents, facilitating new research infrastructure, supporting spin-offs management and the development of specific technology transfer activities and the implementation of particular technology transfer projects in a triple helix system: implementing and/or facilitating research contracts, consultancy, or other specific services. Research seeks a more in-depth understanding than required by the immediate needs of the original problem, ideally giving rise to new questions of conceptual importance [16]. This Hypothesis individually tested whether research activities have influenced technology transfers.

$\mathrm{HO}_{2}$ : Involvement of stakeholders on technology transfers influences technology transfer.

The multiple dimensions of technology transfer mean there are many potential stakeholders, including innovators, developers, owners, suppliers, buyers, recipients, users, consumers, financiers, donors, governments (including policymakers and regulators), insurers, international institutions, and non-governmental and community-based organizations. The stakeholders involved in any specific 
transaction will depend on the type and status of the technology and the associated nature of the transfer pathway [17].

All stakeholders must have the necessary knowledge and skills to perform the roles and tasks expected of them in technology transfer. High levels of awareness, motivation, and empowerment within the public and private sectors and in civil society will help ensure that people, communities, and broader organizations can adapt continuously to new circumstances and challenges that drive and arise from technology transfer.

\section{Research Methodology}

\subsection{Research Design}

The research method was designed robustly to achieve valid data concerning the study of technology transfer in construction management. The data collection tool, a questionnaire, was tested on $10 \%$ of the sample of the questionnaires to validate whether it is appropriate and convenient. It was analyzed using six respondents. Questionnaire surveys were used to collect data. This study used a quantitative design method. The questionnaire was designed to capture data on factors influencing technology transfer in Nigeria.

\subsection{Target Population}

In the research, the target population from whom information was obtained is the architects, quantity surveyors, and engineers within Nigeria. These professions are very resourceful as they are considered highly influential in decision making during the construction process. Also, Nigeria has the highest population density. It also has the highest number of building professionals and construction activities. Architects and engineers being the designers of any construction concept, they dictate the materials and technologies to be used to render the result, functional, durable and environmentally friendly. Therefore, sustainable construction commences with them.

As they dictate on the appropriate technologies to use, they also advise the building owners on their efficiency and effectiveness in the long run. Architects also oversee the construction process, where the role of project managers has not fully developed as is the case in Nigeria. They are therefore to ensure sustainable construction practices are being carried out during construction.

Quantity surveyors are essential in this study as most building owners are faced with resource constraints; hence the use of sustainable technologies is controlled by this constraint. The quantity surveyor has to budget and control costs as well as to advice on alternative technologies within the financial obstacles to ensure value for money with sustainable construction. These professions, therefore, influence the inflow of new technology significantly.

\subsection{Sampling Method}

The sampling method adopted by the analysis is the stratified random sampling. 
Sampling is the process of selecting units like people from accessible population so as to fairly generalize results to the target population [18]. Stratification of the society is also viewed as one way of reducing sampling error because the allocation of population members into strata restricts the variance within the range of values in each layer. The study assumed a confidence level of $95 \%$ meaning the response achieved was within either plus or minus $5 \%$ of the actual state of affairs in the Nigerian construction industry.

The adequate sample size was established by applying the statistical method below

$$
n=\frac{Z^{2} p q N}{\mathrm{e}^{2}(N-1)+Z^{2} p q}
$$

where:

$N=$ Size of the population (average number of registered architectural, quantity surveying and engineering firms).

$n=$ sample size.

$p=$ sample proportion.

$q=1-\mathrm{p}$.

$\mathrm{e}=$ acceptable error $(\mathrm{e}=0.05)$ i.e. estimates to be within $5 \%$ of the true value.

$\mathrm{Z}=$ value of the standard variant at a confidence level (area under a normal curve in a distribution table).

(Source: Chava F and Nachmias D, 1969)

$$
n=\frac{(1.96)^{2} \times(0.95) \times(1-0.95) \times(152+264+236) / 3}{(0.05)^{2} \times[((152+264+236) / 3)-1]+(1.96)^{2} \times 0.95 \times(1-0.95)}
$$

= 55 Architects, Quantity surveyors, and engineering firms.

Source (Researcher, 2018).

\subsection{Research Instruments}

Research instruments are the techniques or methods of data collection [19]. A survey which is based on some form of random sampling technique will produce a sample which is representative of the particular population under study and will produce findings which may be generalized to the wider population [20].

The research adopts a trend study; a type of longitudinal design where different samples of targeted population are asked the same questions. The questionnaires comprised of both closed and open-ended questions. The former questions were more in number since possible answers accompany them that a respondent can choose from. They are easy to analyze because their information content is short. Open-ended questions were appropriate to the study because the researcher was interested in in-depth information from the respondents to air out their views. Section A of the questionnaire contained the demographic information of the participants (age, professional qualifications, and length of practice). Sections B C and D included questions relating to the objectives of the study (Table 2). 
Table 2. Objectives of each section in the questionnaire.

\begin{tabular}{cl}
\hline Section & \multicolumn{1}{c}{ Objective } \\
\hline A & Assess the status of sustainable building to Nigerians' construction industry. \\
B & $\begin{array}{l}\text { Explore the influence of research on sustainable building construction on the suc- } \\
\text { cess of technology transfer }\end{array}$ \\
C & $\begin{array}{l}\text { Investigate the impact of the involvement of stakeholders in building construction } \\
\text { on the success of technology transfer }\end{array}$ \\
\hline
\end{tabular}

\subsection{Data Analysis}

Statistical procedures were utilized to evaluate the survey statistics to answer the research questions. Data collected was analyzed quantitatively. Quantitative data were examined using the Statistical Package for Social Sciences (SPSS). The statistics calculated included frequencies, means, percentages, and trends. The analysis of the data was then made within the scope of the research problem.

\subsection{Reliability of the Data Collection Instrument}

In this research, the data collection tool (questionnaire) was examined on $10 \%$ of the sample of the questionnaires to make sure that it is relevant and compelling. It was pre-tested on 6 respondents.

\subsection{Validity of Data Collection Instrument}

For construct validity, the surveys were categorized into a number of sections to make sure that every part assesses information for a particular objective and also provide the same close ties to the conceptual framework for this study.

\section{Results and Discussion}

In this section, data has been analyzed, interpreted and the results of the study presented. The results were based on the collection of data on factors influencing the transfer of technology for sustainable construction in Nigeria. Data from architects, quantity surveyors and engineers were used to answer the research questions.

\subsection{Sustainable Construction in Nigeria}

This section of the paper examines the knowledge of construction consultants on sustainable construction. It also discusses their view on the status of sustainability in construction in Nigeria. The respondents were asked to give their opinion on elements of construction and factors affecting technology transfer in its potential to implement sustainable construction. This question is a reflection of the technological status in the construction industry as a means of developing sustainable construction.

Status of Sustainable Construction in Nigeria

The question sought to establish the professional perception of sustainability in construction. This helped to determine whether the professionals were aware of 
the scope and the purpose of sustainable construction. The responses were as follows: (Table 3).

Low environmental impacts are the most highly perceived element of sustainability by all the professional respondents (100\%). All the respondent architects also indicated resource efficiency as an element of sustainable construction while $17(85.8 \%)$ of the respondent quantity surveyors and $9(81.8 \%)$ of the engineers identified resource efficiency as an element of sustainable construction. The study found out that 16 (94.1\%) of the architects who responded identified economic advantages as an element of sustainable construction while 18 (90\%) of the respondent quantity surveyors and 8 (72.7\%) of construction engineers identified economic benefits as an element of sustainable construction. Social advantages were the least recognized element of sustainable construction by 15 $(88.2 \%)$ of the respondent architects, $13(65 \%)$ of the respondent quantity surveyors and 7 (3.6\%) of the respondent construction engineers.

\subsection{Factors Affecting Technology Transfer}

The primary purpose of this investigation was to identify the features influencing the transfer of technology to enable sustainable building in Nigeria's construction industry. To achieve this objective, the researcher listed some indicators in research on the sustainability of technology transfer and the involvement of stakeholders on how they were influencing technology transfer.

The findings from Table 4 indicate that majority of the respondents (46\%) report that lack of stakeholder involvement in scientific and technological infrastructure influence technology transfer. The study also shows that Lack of and ineffectiveness of professional bodies responsible for the screening and adoption of successful and appropriate technologies affect the success of technology transfer. Majority of the respondents 33\% agreed to the statement. Majority of the respondents $52 \%$ were neutral that Lack of performance measurement by stakeholders for measuring and monitoring the technological progress. Majority of the interviewed respondents also said that Lack of government's fund and policies as a stakeholder to support technology transfer initiatives affects technology transfer. Lack of government's fund and plans as a stakeholder to promote technology transfer initiatives also was seen as another setback to technology transfer. About $93 \%$ of the participants admitted that absence of and ineffectiveness of technology diffusion networks (professional institutions, a professional journal, lectures, conferences) affect technology transfer. Also, the findings indicated that Poor linkage between research and application affect technology transfer. Finally, Concentration on new research rather than documentation and dissemination of results was seen to change technology transfer.

\subsection{Inferential Statistics}

The inferential statistics were obtained by carrying regression analyses. The results are presented in the subsections that follow. 
Table 3. Elements of sustainable construction.

\begin{tabular}{ccccccc}
\hline Response & Architects & $\%$ & $\begin{array}{c}\text { Quantity } \\
\text { surveyors }\end{array}$ & $\%$ & $\begin{array}{c}\text { Construction } \\
\text { Engineers }\end{array}$ & $\%$ \\
\hline Low environmental impacts & 17 & 100 & 20 & 100 & 11 & 100 \\
Resource efficiency & 17 & 100 & 17 & 85.8 & 9 & 81.8 \\
Economic advantages & 16 & 94.1 & 18 & 90 & 8 & 72.7 \\
Social advantages & 15 & 88.2 & 13 & 65 & 7 & 63.6 \\
\hline
\end{tabular}

Source: Field data (2018).

Table 4. Factors affecting technology transfer.

\begin{tabular}{|c|c|c|c|c|c|}
\hline Statement & $\begin{array}{l}\text { Strongly } \\
\text { disagree }\end{array}$ & disagree & Neutral & agree & $\begin{array}{c}\text { Strongly } \\
\text { agree }\end{array}$ \\
\hline $\begin{array}{l}\text { Absence of stakeholders involved in scientific } \\
\text { and technological infrastructure }\end{array}$ & - & $12 \%$ & $10 \%$ & $32 \%$ & $46 \%$ \\
\hline $\begin{array}{l}\text { Lack of and ineffectiveness of professional } \\
\text { bodies responsible for the screening and } \\
\text { adoption of successful and appropriate } \\
\text { technologies }\end{array}$ & - & $32 \%$ & $35 \%$ & $27 \%$ & $6 \%$ \\
\hline $\begin{array}{l}\text { Lack of performance measurement by } \\
\text { stakeholders for measuring and monitoring } \\
\text { technological progress }\end{array}$ & $12 \%$ & $20 \%$ & $52 \%$ & $12 \%$ & $4 \%$ \\
\hline $\begin{array}{l}\text { Lack of government's fund and policies as a } \\
\text { stakeholder to support technology transfer } \\
\text { initiatives }\end{array}$ & - & $5 \%$ & $25 \%$ & $37 \%$ & $33 \%$ \\
\hline $\begin{array}{l}\text { Lack of and ineffectiveness of technology } \\
\text { diffusion networks (professional institutions, } \\
\text { a professional journal, lectures, conferences, } \\
\text { etc.). }\end{array}$ & - & $5 \%$ & $2 \%$ & $32 \%$ & $61 \%$ \\
\hline $\begin{array}{l}\text { Local firms lack the capability to innovate and } \\
\text { benefit from technology transfer }\end{array}$ & $9 \%$ & $22 \%$ & $12 \%$ & $32 \%$ & $25 \%$ \\
\hline $\begin{array}{l}\text { Low investment in training, education, and } \\
\text { research and development }\end{array}$ & & $6 \%$ & $10 \%$ & $45 \%$ & $39 \%$ \\
\hline $\begin{array}{l}\text { The poor linkage between research and } \\
\text { application }\end{array}$ & - & - & $3 \%$ & $39 \%$ & $58 \%$ \\
\hline $\begin{array}{l}\text { Concentration on new research rather than } \\
\text { documentation and dissemination of results }\end{array}$ & $19 \%$ & $28 \%$ & $35 \%$ & $12 \%$ & $6 \%$ \\
\hline $\begin{array}{l}\text { Lack of information dissemination on new and } \\
\text { successful technologies }\end{array}$ & $2 \%$ & $12 \%$ & $42 \%$ & $31 \%$ & $13 \%$ \\
\hline
\end{tabular}

Source: Field data (2018)

Table 5. Model's Summary.

\begin{tabular}{ccccc}
\hline $\mathbf{R}$ & R Square & $\begin{array}{c}\text { Adjusted R } \\
\text { Square }\end{array}$ & $\begin{array}{c}\text { Std. Error of the } \\
\text { Estimate }\end{array}$ & Durbin-Watson \\
\hline $0.957^{\mathrm{a}}$ & 0.917 & 0.914 & 0.15476 & 1.774 \\
\hline
\end{tabular}

aPredictors: (Constant), Research on sustainability, stakeholder involvement.

Table 5 Illustrates that there is an excellent linear association between the predictor and outcome variables; this is tabulated in the above table. This is ex- 
pressed by a correlation ( $\mathrm{R}$ ) coefficient of 0.957 . A presentation of a strong association between the outcome and predictor variable was determined by the coefficient which was measured by the adjusted R-square gave a value of 0.914 . This explains that the model covers $91.4 \%$ of the overall research while a small percentage of $8.6 \%$ remains uncovered by the regression model. Hair [21] proposed that in academic investigations that concentrate on social problems, $\mathrm{R}^{2}$ values of $0.75,0.50$, or 0.25 for endogenous latent variables can, as a principle, be respectively defined as substantial, moderate or weak.

Durbin Watson test was applied as one of the preliminary criteria for regression to test whether there is any autocorrelation within the model's residuals. Given that the Durbin Watson value was close to 2 (1.774), there was no association in the model's residuals.

The significance of the model was presented using the ANOVA statistics shown in Table 6 . Profitability of $0.00 \%$ was gotten from the F-significance value of $\mathrm{p}=0.000$ which gave incorrect data. Therefore, the model is significant (Table 7).

The result of the regression model is shown below.

All the variables under study were significantly influencing the progress of technology transfer, the Research on sustainability was significant at $99 \%$ confidence interval $(\mathrm{t}=5.460 \mathrm{p}<0.000)$ while involvement of stakeholders was substantial at $99 \%$ confidence interval of $(t=6.049 \mathrm{p}<0.000)$ which were both less than $\mathrm{p}>0.05$. A significance of 0.01 was used since the study wanted to get the most considerable evidence against the null hypothesis. A $99 \%$ confidence interval is more extensive than $95 \%$. Therefore, it's more likely that it will contain the actual value.

\section{Conclusions}

\subsection{Summary of Findings}

The study revealed that technology not only involves equipment's and materials, but it also includes knowledge and skills. Majority of the respondents were of the opinion that combining indigenous and modern building technologies useful research and involvement of stakeholders will efficiently achieve sustainable construction than the use of either technique.

Findings from the study showed that technology transfer has been highly efficient in the adoption of new technologies in Nigeria's construction industry.

Table 6. Analysis of variance (ANOVA).

\begin{tabular}{ccccccc}
\hline \multicolumn{2}{l}{ Model } & $\begin{array}{c}\text { Sum of } \\
\text { Squares }\end{array}$ & df & $\begin{array}{c}\text { Mean } \\
\text { Square }\end{array}$ & F & Sig. \\
\hline & Regression & 28.187 & 4 & 7.046 & 294.204 & $0.000^{\mathrm{b}}$ \\
& Residual & 2.563 & 107 & 0.024 & & \\
& Total & 30.748 & 111 & & \\
\hline
\end{tabular}

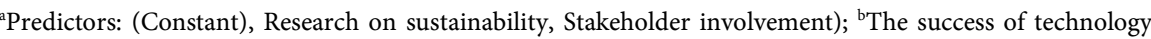
transfer: Dependent Variable. 
Table 7. Regression coefficients.

\begin{tabular}{cccccc}
\hline \multirow{2}{*}{ Model } & \multicolumn{2}{c}{ Unstandardized Coefficients } & $\begin{array}{c}\text { Standardized } \\
\text { Coefficients }\end{array}$ & T & Sig. \\
\cline { 2 - 4 } & B & Std. Error & Beta & & \\
\hline (Constant) & -1.511 & 0.209 & & -7.223 & 0.000 \\
Research on sustainability & 0.364 & 0.067 & 0.219 & 5.460 & 0.000 \\
Involvement of stakeholders & 0.469 & 0.078 & 0.380 & 6.049 & 0.000 \\
\hline
\end{tabular}

${ }^{a}$ The success of sustainability: Dependent Variable.

This explains the significance of technology transfer in attaining sustainable construction as the adoption of new technologies is among the major success factors required to enable sustainable development in Nigeria.

The findings reveal that matters regarding research and development also significantly influence technology transfer meant for sustainable construction. These include low investment in training, education, and research and development, concentration on new research rather than documentation and dissemination of results and reduced linkage between research and application.

\subsection{Managerial Implications}

After studying the factors that influence technology transfer for sustainable construction in Nigeria, it has been concluded that the significant factors affecting technology transfer include consumer based factors such as reluctance to take risks and unawareness of new construction technologies.

Government policies influence technology adoption through taxation, imports/exports, innovation guidelines, education and capacity-building, regulatory programs, institutional development, credit, and investment. Research-based factors such as low investment in training, education, and Research and Development, the reduced linkage between research and application and the concentration on new research rather than documentation and dissemination of results also contribute mainly to the inefficient technology transfer process.

Construction Companies Infrastructure and industrialization based factors are captured as having a significant influence on the technology transfer process.

\subsection{Directions for Future Research}

Technology transfer is a management science which has not been researched in Nigeria. This says much about the many different aspects surrounding technology transfer which has to be examined. From the findings of the research, further research has been recommended in the areas below; Research is needed to investigate the role of the informal sector and its contribution to the total output of the industry as well as the entire economy. Additionally, the part of the everyday sector in technology transfer and the adoption of appropriate materials and technologies could be explored. Research oriented towards identifying a comprehensive approach for the selection of articles and choice of techniques to 
comply with sustainable development principles is required. Finally, different stakeholders have different roles as defined in the study. Further research is necessary to assess the effectiveness of each stakeholder in the technology transfer process in Nigeria's construction industry.

\section{Conflicts of Interest}

The authors declare no conflicts of interest regarding the publication of this paper.

\section{References}

[1] Kibert, C.J., Chini, A. and Languell, J. (2000) Deconstruction as an Essential Component of Sustainable Construction. In Proceedings of the Second Southern African Conference on Sustainable Development in the Built Environment, Pretoria, 1-5.

[2] Vanegas, M. (2009) Development, Justice, and Technology Transfer in China: The Case of HP and Legend. Journal of Business Ethics, 89, 157-166.

[3] CIB (1999) Agenda 21 for Sustainable Construction: Why, How and What. Building Research \& Information, 27, 347-353. https://doi.org/10.1080/096132199369174

[4] Augenbroe, G.L.M., Pearce, A.R., Guy, B. and Kibert, C.K. (1998) Sustainable Construction in the USA; a Perspective to the Year 2010. Sustainable Development and the Future of Construction, 225.

[5] US Green Building Council: Leadership in Energy and Environmental Design (LEED) Green Building Rating System. www.usgbc.org

[6] IMF Development Report 2008.

[7] Datta, M. (2000) Challenges Facing the Construction Industry in Developing Countries. 2nd International Conference on Construction in Developing Countries. Challenges Facing the Construction Industry in Developing Countries, Gaborone.

[8] United Nations Development Program (UNDP) (2007) Energizing the Least Developed Countries to Achieve the Millennium Development Goals: The Challenges and Opportunities of Globalization. United Nations, New York.

[9] van Egmond-deWilde de Ligny, E. and Erkelens, P. (2008) Construction Technology Diffusion in Developing Countries' Limitations of Prevailing Innovation Systems. Journal of Construction in Developing Countries, 13, 43-63.

[10] Ofori, G. (2000) Challenges of Construction Industries in Developing Countries: Lessons from Various Countries. 2nd International Conference on Construction in Developing Countries: Challenges Facing the Construction Industry in Developing Countries, Gaborone, 15-17.

[11] Graham, B.S. (2008) Identifying Social Interactions through Conditional Variance Restrictions. Econometrica, 76, 643-660. https://doi.org/10.1111/j.1468-0262.2008.00850.x

[12] Moavenzadeh (1978) The Role of the Construction Industry in the Development Process. Public Policy XXII, 2, 219-241.

[13] Ofori, G. (1993) Research on Construction Industry Development at the Crossroads. Construction Management and Economics, 11, 175-185. https://doi.org/10.1080/01446199300000017

[14] Olander, S. (2007) Stakeholder Impact Analysis in Construction Project Management. Construction Management and Economics, 25, 277-287.

https://doi.org/10.1080/01446190600879125 
[15] Watermeyer, R.B. (2001) Appropriate Construction Technologies and Standards: A Key to Sustainable Development in Africa. Keynote Address for the African Engineers Forum on the Theme of Sustainable Development in Africa, Zimbabwe.

[16] Brooks, J.G. (1999) In Search of Understanding: The Case for Constructivist Classrooms. ASCD.

[17] Benaroch, M. (2001) Option-Based Management of Technology Investment Risk. IEEE Transactions on Engineering Management, 48, 428-444. https://doi.org/10.1109/17.969422

[18] Orodho, J. (2012) Elements of Education and Social Science Research Methods. Masola Publishers, Nairobi.

[19] Kasomo, D. (2006) Research Methods. Egerton University Press, Egerton.

[20] Mathers, N., Fox, N. and Hunn, A. (2007) Surveys and Questionnaires. The NIHR RDS for the East Midlands/Yorkshire \& the Humber.

[21] Hair, J.F., Ringle, C.M. and Sarstedt, M. (2013) Partial Least Squares Structural Equation Modeling: Rigorous Applications, Better Results and Higher Acceptance. Long Range Planning, 46, 1-12. https://doi.org/10.1016/j.lrp.2013.01.001 